\title{
Diversity and Inclusion Education
}

Follow this and additional works at: https://jdc.jefferson.edu/skmcdiversity

Part of the Medicine and Health Sciences Commons Let us know how access to this document benefits you

\section{Recommended Citation}

(2017) "Diversity and Inclusion Education," Office of Diversity \& Inclusion Initiatives Newsletter. Vol. 2 : Iss. 1 , Article 4.

Available at: https://jdc.jefferson.edu/skmcdiversity/vol2/iss1/4

This Article is brought to you for free and open access by the Jefferson Digital Commons. The Jefferson Digital Commons is a service of Thomas Jefferson University's Center for Teaching and Learning (CTL). The Commons is a showcase for Jefferson books and journals, peer-reviewed scholarly publications, unique historical collections from the University archives, and teaching tools. The Jefferson Digital Commons allows researchers and interested readers anywhere in the world to learn about and keep up to date with Jefferson scholarship. This article has been accepted for inclusion in Office of Diversity \& Inclusion Initiatives Newsletter by an authorized administrator of the Jefferson Digital Commons. For more information, please contact: JeffersonDigitalCommons@jefferson.edu. 


\section{Diversity and Inclusion Education}

In the 2016-2017 academic year, two then-second year SKMC students. Linda Magana and Kevin Guttierez, created and conducted a "Race and Medicine" course that first year SKMC students could receive credits for their Humanities Course.

The Office of the Dean at SKMC has created a new lecture series called, "Confronting Racism, Bias, and Social Injustice in Healthcare." This first-of-akind at Jefferson educational series is meant to educate on this important topic and to allow us to begin the discussions needed to move us forward in our quest to provide the best patient care. The content was developed by Drs. John Spandorfer, Traci Trice and Bernie Lopez. The lectures include:

\section{"Black Man in a White Coat"}

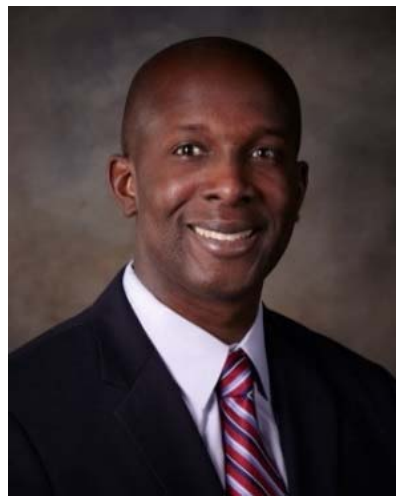

Damon Tweedy, MD

Assistant Professor of Psychiatry, Duke University School of Medicine,

September 12, 2017

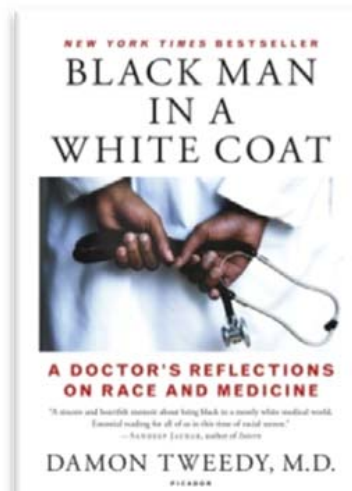

Published by Jefferson Digital Commons, 2017
Punching Ideological Extremism in the Face: A Neuroscience-based Approach to Bridging the Partisan Divide

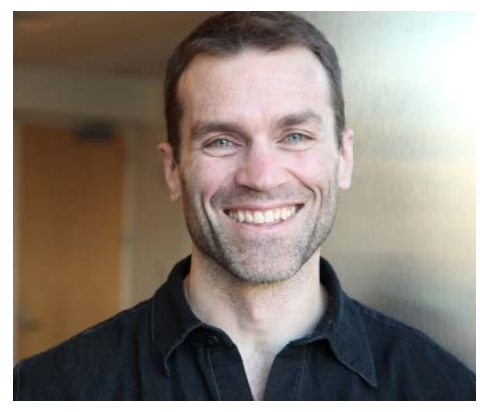

Emile Bruneau, PhD

Visiting Professor, Annenberg School of Communication, University of Pennsylvania

Research Scientist, Brain and Cognitive Sciences

Massachusetts Institute of Technology

November 14, 2017

\section{Mistreating Health Inequities in the Genomic Era}

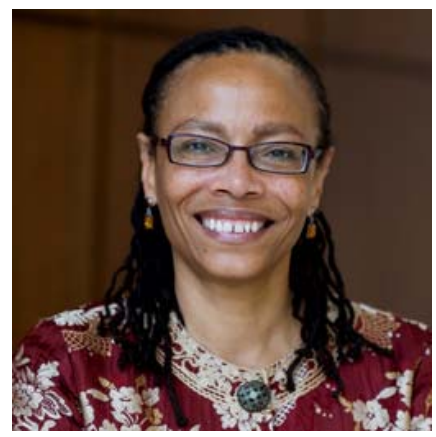

Dorothy Roberts, JD

The George A. Weiss University Professor of Law and Sociology and the Raymond Pace and Sadie Tanner Mossell Alexander Professor of Civil Rights

Professor of Africana Studies and Director, Program on Race, Science and Society, University of Pennsylvania

April 24, 2018

\section{An Introduction to Medical Racism}

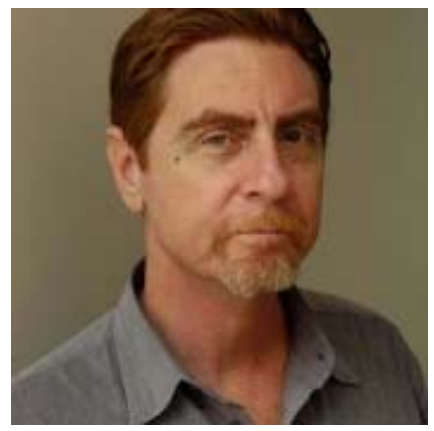

John Hoberman, PhD

Professor of Germanic Studies, College of Liberal Arts, University of Texas at Austin

Author of "Black \& Blue" on the topic of structural racism and medicine

March 2018

Connelly Auditorium, Noon-1 pm 